\title{
Activation of muscarinic receptors inhibits glutamate-induced GSK-3 $\beta$ overactivation in PC12 cells
}

\author{
Ke MA, Li-min YANG, Hong-zhuan CHEN, Yang LU* \\ Department of Pharmacy, Shanghai Jiao Tong University School of Medicine, Shanghai 200025, China
}

\begin{abstract}
Aim: To investigate the actions of the muscarinic agonist carbachol on glutamate-induced neurotoxicity in PC12 cells, and the underlying mechanisms.

Methods: PC12 cells were treated with different concentrations of glutamate for 24 or $48 \mathrm{~h}$. The cell viability was measured using MTT assay, and the expression and activation of GSK-3 $\beta$ were detected with Western blot. $\beta$-Catenin translocation was detected using immunofluorescence. Luciferase reporter assay and real-time PCR were used to analyze the transcriptional activity of $\beta$-catenin. Results: Glutamate $(1,3$, and $10 \mathrm{mmol} / \mathrm{L})$ induced PC12 cell death in a dose-dependent manner. Moreover, treatment of the cells with glutamate $(1 \mathrm{mmol} / \mathrm{L})$ caused significant overactivation of GSK-3 $\beta$ and prevented $\beta$-catenin translocation to the nucleus. Pretreatment with carbachol $(0.01 \mu \mathrm{mol} / \mathrm{L})$ blocked glutamate-induced cell death and GSK-3 $\beta$ overactivation, and markedly enhanced $\beta$-catenin transcriptional activity.

Conclusion: Activation of muscarinic receptors exerts neuroprotection in PC12 cells by attenuating glutamate-induced GSK-3 $\beta$ overactivation, suggesting potential benefits of muscarinic agonists for Alzheimer's disease.
\end{abstract}

Keywords: muscarinic receptors; carbachol; neuroprotection; glutamate; excitotoxicity; GSK-3ß; $\beta$-catenin; PC12 cell; Alzheimer's disease

Acta Pharmacologica Sinica (2013) 34: 886-892; doi: 10.1038/aps.2013.42; published online 20 May 2013

\section{Introduction}

Alzheimer's disease (AD), a neurodegenerative disorder affecting patients worldwide, is associated with a loss of cholinergic neurons, which causes profound memory disturbances $^{[1]}$. AD patients benefit from treatment with agonists of the muscarinic receptor $(\mathrm{mAChR})$, which seem to restore lost cholinergic function ${ }^{[2,3]}$. They also benefit from treatment with neuroprotective agents, which can alter the disease progression $^{[4]}$. One novel therapeutic strategy for AD involves not only increasing cholinergic function but also slowing or stopping the pathological progression of the disease. Recent studies elucidating the mechanism by which muscarinic agonists protect cells from apoptosis induced by a variety of stimuli have suggested that the neuroprotective effects of $\mathrm{mAChR}$ activation may do more than address the symptoms of cognitive decline ${ }^{[5-9]}$. Rather, these agonists might affect the disease progression itself. The present study addressed the ability of

\footnotetext{
* To whom correspondence should be addressed.

E-mail luyangssmu@yahoo.com

Received 2012-09-29 Accepted 2013-03-20
}

these agonists to protect PC12 cells from glutamate-induced cell death and the mechanism underlying this process, as the $\mathrm{Ca}^{2+}$ overload, oxidative stress and neuronal death associated with glutamate-induced excitotoxicity are thought to be key factors in the pathogenesis of $\mathrm{AD}^{[10-15]}$.

Glycogen synthase kinase-3 $\beta$ (GSK-3 $\beta$ ), a serine/threonine kinase abundant in the central nervous system, plays an established role in cell survival ${ }^{[16,17]}$. Several apoptotic stimuli appear to be involved in GSK-3 $\beta$ activation ${ }^{[18]}$. Aberrant overactivation of GSK-3 $\beta$ induces neuronal death ${ }^{[19-23]}$. Muscarinic agonists reduce tau hyperphosphorylation and counteract A $\beta$-toxicity, the hallmarks of AD, by inhibiting GSK-3 $\beta^{[7,24]}$. This effect suggests that overactivation of GSK-3 $\beta$ could be attenuated through muscarinic signaling. The present work investigates whether overexpression or overactivation of GSK-3 $\beta$ plays a role in glutamate-mediated excitotoxicity and whether the GSK-3 $\beta / \beta$-catenin signaling pathway plays a role in the protective effect of $\mathrm{mAChR}$ activation against glutamate-induced neurotoxicity.

Inhibition of GSK-3 $\beta$ activity and activation of mAChR are both therapeutic methods against $\mathrm{AD}^{[25-27]}$. This study may 
reveal a new mechanism by which muscarinic agonist treatment provides therapeutic benefits to AD patients; the agents counteract glutamate-induced neurotoxicity by inhibiting the GSK-3 $\beta / \beta$-catenin signaling pathway.

\section{Materials and methods Chemicals}

RPMI-1640 medium was purchased from Gibco (New York, USA). Carbachol, MTT, and L-glutamic acid monosodium were purchased from Sigma (St Louis, MO, USA).

\section{Cell culture and treatment}

PC12 cells were obtained from the Cell Bank of China (Shanghai, China) and cultured in RPMI-1640 medium supplemented with $10 \%$ fetal bovine serum in a humidified atmosphere with $5 \% \mathrm{CO}_{2}$ at $37{ }^{\circ} \mathrm{C}$. One day before the experiment, cells were seeded in 96-well $\left(1.0 \times 10^{4}\right.$ cells/well), 24 -well $\left(4.0 \times 10^{4}\right.$ cells/well), and 6-well $\left(2.0 \times 10^{5}\right.$ cells/well $)$ plates.

\section{Cell viability assay}

PC12 cells were plated in 96-well culture plates at $1.0 \times 10^{4}$ cells/well. After treatment, cell viability assays were performed using the MTT method. MTT in PBS was added to the cultures at a final concentration of $0.5 \mathrm{mg} / \mathrm{mL}$. After further incubation at $37^{\circ} \mathrm{C}$ for $4 \mathrm{~h}$, the medium was carefully removed and formazan crystals were dissolved in $150 \mu \mathrm{L}$ DMSO per well. Absorbance at $490 \mathrm{~nm}$ was measured with a plate reader (Bio-tek, VT, USA).

\section{Immunoblots}

In the current work, immunoblots were performed for various purposes and were adjusted for different protein samples. Cells were washed with PBS and lysed with a lysis buffer (50 mmol/L Tris-HCl, pH 7.5, 150 mmol/L NaCl, 1\% NP-40, $0.5 \%$ sodium deoxycholate, $0.1 \%$ SDS, $1 \mathrm{mmol} / \mathrm{L}$ EDTA, 1 $\mathrm{mmol} / \mathrm{L}$ sodium orthovanadate, $10 \mathrm{mmol} / \mathrm{L}$ sodium fluoride, $4 \mu \mathrm{g} / \mathrm{mL}$ leupeptin, $1 \mu \mathrm{g} / \mathrm{mL}$ aprotinin, and $100 \mu \mathrm{g} / \mathrm{mL}$ PMSF). Proteins were loaded onto $10 \%$ or $12 \%$ SDS-PAGE gels, transferred to nitrocellulose membranes, detected using the proper primary and secondary antibodies, and visualized using chemiluminescence (Pierce Biotechnology, USA). Various primary antibodies were used, including anti-phosphorSer9-GSK3 $\beta$ (1:500, KeyGEN, China), anti-total-GSK3 $\beta$ (1:500, KeyGEN, China), anti- $\beta$-catenin (1:1000, Abcam, UK), and anti- $\beta$-actin (1:5000, Abcam, UK).

\section{Immunofluorescence}

After treatment, PC12 cells were washed with PBS, fixed with $4 \%$ paraformaldehyde, and permeabilized with $0.2 \%$ Triton $X-100$. Endogenous cellular $\beta$-catenin was detected with polyclonal anti- $\beta$-catenin $(1: 1000)$ and fluorescent isothiocyanate (FITC)-conjugated anti-rabbit antibody (1:100, DAKO A/S, Denmark). Nuclei were stained with 4',6-diamidino-2-phenylindole (DAPI). Cells were examined under an Axioplan 2 fluorescent microscope (Zeiss, Germany).

\section{Luciferase reporter assays}

PC12 cells were cultured on a 10-cm dish and treated with a DNA mixture consisting of $8 \mu \mathrm{g}$ of the appropriate TOPluciferase and $800 \mathrm{ng}$ of the effector/control plasmids per well using Lipofectamine 2000 (Invitrogen, CA, USA). Cells were incubated with DNA/lipofectamine complexes for $5 \mathrm{~h}$, then maintained in media with $10 \%$ FBS for $16 \mathrm{~h}$ and seeded in 24-well plates for post-treatment with $1 \mathrm{mmol} / \mathrm{L}$ glutamate. The luciferase (LUC) activity was assayed with the dualfirefly/Renilla luciferase reporter system (Promega, WI, USA) according to the manufacturer's instructions. Relative light units were measured in a Femtomaster FB12 chemiluminometer (Berthold, Pforzheim, Germany).

\section{RT-PCR}

Total RNA was extracted from $0.8 \times 10^{6}$ cells using TRIzol reagent (Gibco, CA, USA) according to the manufacturer's instructions. RNA concentration was measured by spectrophotometric measurement at $260 \mathrm{~nm}$. cDNA was synthesized using random 9-mer primers and AMV reverse transcriptase (Takara, Shiga, Japan).

\section{Plasmid constructs}

The cDNA constructs for rat $\beta$-catenin were generated by PCR using the following primers containing Sal I and $B a m \mathrm{H}$ I restriction sites: $\beta$-catenin-Sal I-forward: 5'-GCGTCGACACAATGGCTACTCAAG-3'; $\beta$-catenin-BamH I-reverse: 5'-CGCGGATCCTTACAGGTCGGTATC-3'. The PCR-amplified fragments were cut with $\mathrm{Sal} \mathrm{I} / \mathrm{BamH} \mathrm{I}$ and cloned into the pEGFP-C1 plasmid (Clontech, CA, USA).

\section{Real-time PCR}

Up to $1 \mu \mathrm{L}$ template cDNA was used. Thermal cycling conditions were $95^{\circ} \mathrm{C}$ for $60 \mathrm{~s}$, followed by 45 cycles of $95^{\circ} \mathrm{C}$ for $30 \mathrm{~s}, 56^{\circ} \mathrm{C}$ for $30 \mathrm{~s}$ and $72^{\circ} \mathrm{C}$ for $35 \mathrm{~s}$. Primer efficiency was $>90 \%$, which was confirmed with a standard curve spanning four orders of magnitude. After the reactions, the data were exported using 7300 System Software v1.3.0 (Applied Biosystems, CA, USA) and analyzed. The following primers were used (Table 1).

\section{Statistical analysis}

The data are presented as the mean \pm SD. Statistical signifi-

Table 1. Primers for real-time PCR.

\begin{tabular}{cc}
\hline \multicolumn{1}{c}{ Gene } & \multicolumn{1}{c}{ Sequences } \\
\hline \multirow{2}{*}{ Cyclin D1 } & 5'-TGCTGCAAATGGAACTGCTTCTGG-3' \\
& 5'-AAGGTCTGTGCATGTTTGCGGATG-3' \\
Engrailed-1 & 5'-AGAAGGATTCCAAGTCCAGCGAGA-3' \\
& 5'-TGAAGAAGTTGGTGATGCGATGCG-3' \\
Connexin43 & 5'-TCATCTTCATGCTGGTGGTGTCCT-3' \\
3-Actin & 5'-TGGTGAGGAGCAGCCATTGAAGTA-3' \\
& 5'-TTGCTGATCCACATCTGCT-3' \\
& 5'-GACAGGATGCAGAAGGAGAT-3' \\
\hline
\end{tabular}


cance of differences between groups was assessed by using a Student-Newman-Keuls test, where $P<0.05$ indicated a significant difference.

\section{Results}

Glutamate-induced neurotoxicity was accompanied by GSK-3 $\beta$ overactivation and decreased $\beta$-catenin nuclear translocation in PC12 cells

Glutamate treatment at 1, 3, or $10 \mathrm{mmol} / \mathrm{L}$ for 24 or $48 \mathrm{~h}$ induced excitotoxicity in PC12 cells. The viability of PC12 cells treated with glutamate significantly decreased in a timeand dose-dependent manner relative to the control group. The cellular survival rates after $48 \mathrm{~h}$ treatment with 1,3 , and $10 \mathrm{mmol} / \mathrm{L}$ glutamate were $82.9 \% \pm 2.4 \%, 41.1 \% \pm 3.9 \%$, and $23.2 \% \pm 1.1 \%$, respectively (Figure $1 \mathrm{~A}$ ). We next assayed for GSK-3 $\beta$ phosphorylation in PC12 cells by immunoblotting with antibodies against phosphorylated GSK-3 $\beta$ (Ser9). After treating PC12 cells with 1, 3, or $10 \mathrm{mmol} / \mathrm{L}$ glutamate for $8 \mathrm{~h}$, GSK-3 $\beta$ was overactivated, as indicated by decreased phosphorylation levels (Figure 1B). These results are consistent with previous reports demonstrating that GSK-3 $\beta$ could be negatively regulated by phosphorylation at Ser9 ${ }^{[28,29]}$. However, phosphorylation levels at Ser9 did not change after 24 or $48 \mathrm{~h}$ glutamate treatment (data not shown).

GSK-3 $\beta$ participates in the Wnt pathway, which regulates $\beta$-catenin stability. The present work evaluated the intracel- lular distribution of $\beta$-catenin in PC12 cells during glutamate treatment. $\beta$-catenin nuclear localization was detected in transiently transfected PC12 cells using GFP- $\beta$-catenin. Cells incubated with $1 \mathrm{mmol} / \mathrm{L}$ glutamate displayed less $\beta$-catenin nuclear localization (Figure 1C).

mAChR activation protected PC12 cells from glutamate-induced cell death and GSK-3 $\beta$ overactivation

PC12 cells were pretreated with $0.001 \mu \mathrm{mol} / \mathrm{L}$ or $0.01 \mu \mathrm{mol} / \mathrm{L}$ muscarinic agonist carbachol for $24 \mathrm{~h}$, followed by $3 \mathrm{mmol} / \mathrm{L}$ glutamate treatment for $48 \mathrm{~h}$. The $0.001 \mu \mathrm{mol} / \mathrm{L}$ or 0.01 $\mu \mathrm{mol} / \mathrm{L}$ carbachol pretreatment increased cell viability by $85.71 \% \pm 4.9 \%$ and $94.55 \% \pm 3.7 \%$, respectively (Figure $2 \mathrm{~A}$ ). As $0.01 \mu \mathrm{mol} / \mathrm{L}$ carbachol elicited a more effective response, this concentration was used in subsequent cell signal transduction experiments. Carbachol treatment $(0.01 \mu \mathrm{mol} / \mathrm{L})$ diminished glutamate-evoked Ser9 GSK-3 $\beta$ phosphorylation deregulation (Figure 2B).

mAChR activation reversed glutamate repression of $\beta$-catenin nuclear translocation in PC12 cells

There was no change in $\beta$-catenin protein levels as detected by immunoblotting (Figure 3A). Immunofluorescence analysis with antibodies specific to $\beta$-catenin and the nuclear marker DAPI revealed less nuclear $\beta$-catenin in cells treated with $1 \mathrm{mmol} / \mathrm{L}$ glutamate than in untreated cells. Pretreatment

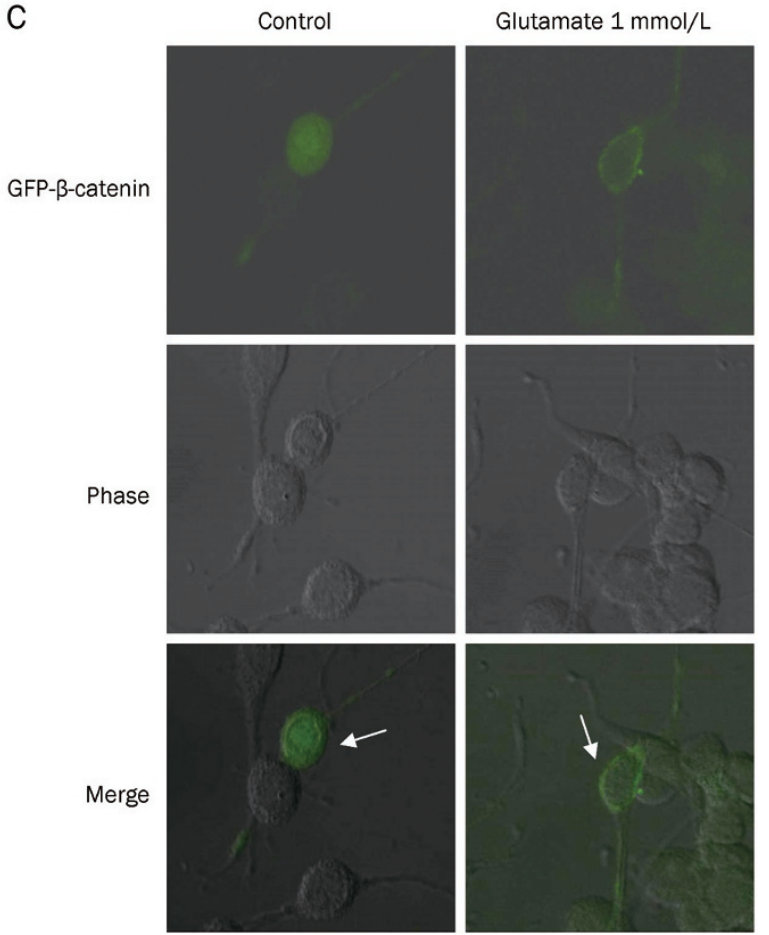

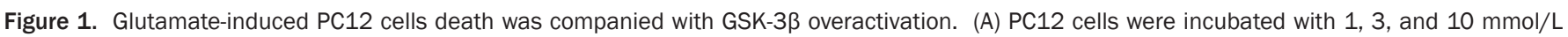

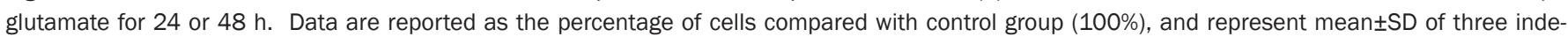

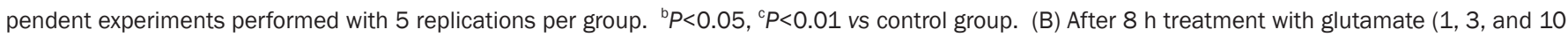

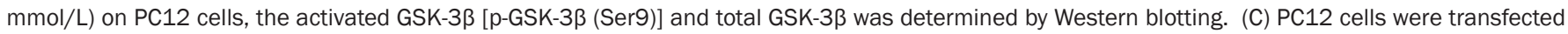
with GFP- $\beta$-catenin. Cells were incubated with or without $1 \mathrm{mmol} / \mathrm{L}$ glutamate $24 \mathrm{~h}$ after transfection. 


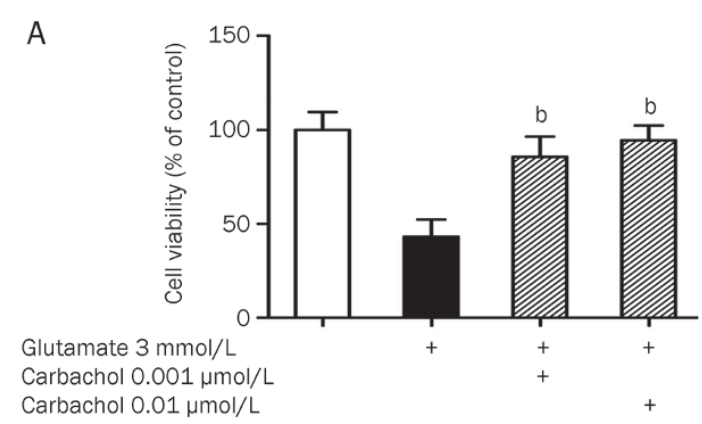

B
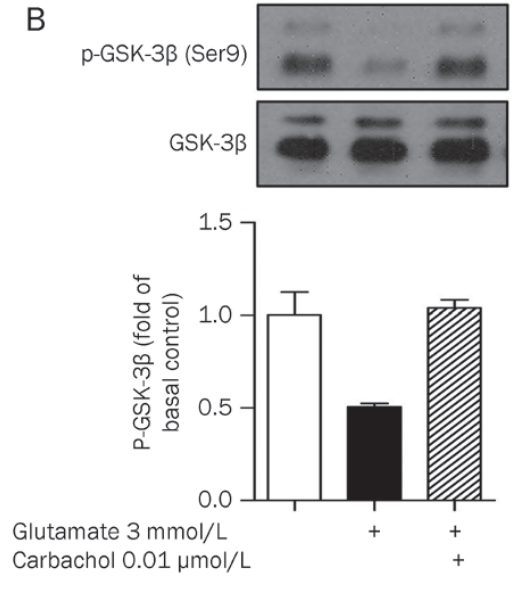

Figure 2. Activation of $m A C h R$ protected PC12 cells from glutamate-induced cell death and GSK-3ß overactivation. (A) After pre-treatment with 0.001 $\mu \mathrm{mol} / \mathrm{L}, 0.01 \mu \mathrm{mol} / \mathrm{L}$ carbachol for $24 \mathrm{~h}$, cultures were exposed to $3 \mathrm{mmol} / \mathrm{L}$ glutamate for $48 \mathrm{~h}$ and the cell viability was analyzed by MTT. Data are reported as the percentage of cells compared with control group (100\%), and represent the mean \pm SD of three independent experiments performed with 5 replications per group. ${ }^{b} \mathrm{P}<0.05$ vs injury group. (B) Pre-treatment of PC12 cells with $0.01 \mu \mathrm{mol} / \mathrm{L}$ carbachol for $24 \mathrm{~h}$, after $8 \mathrm{~h}$ treatment of 3 $\mathrm{mmol} / \mathrm{L}$ glutamate, the up-regulated GSK-3 $\beta$ activation can be reduced.

A
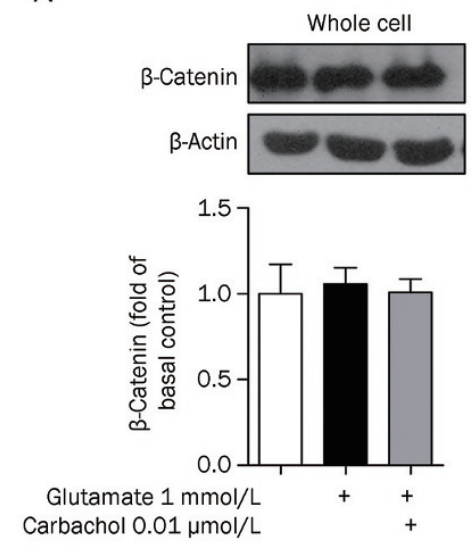

C
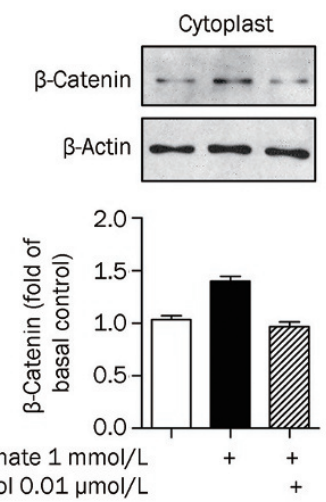

B
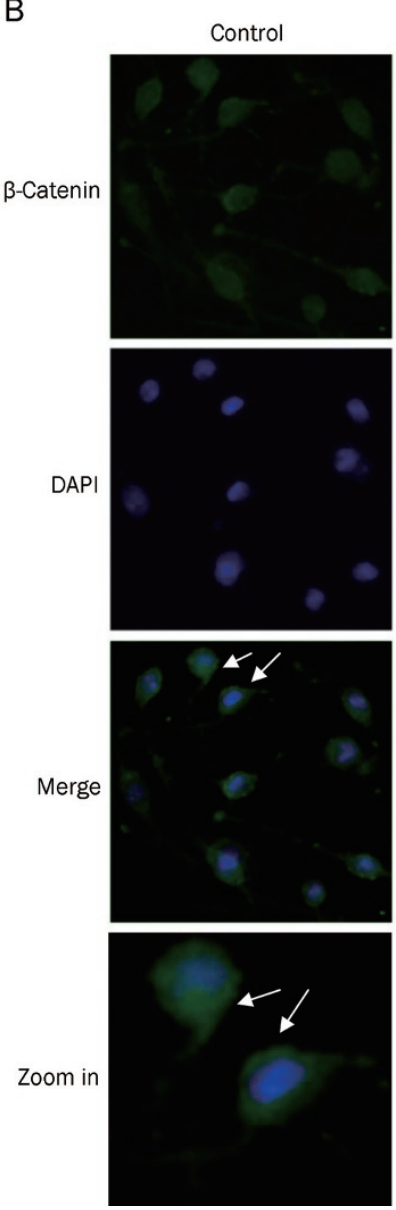

Glutamate $1 \mathrm{mmol} / \mathrm{L}$
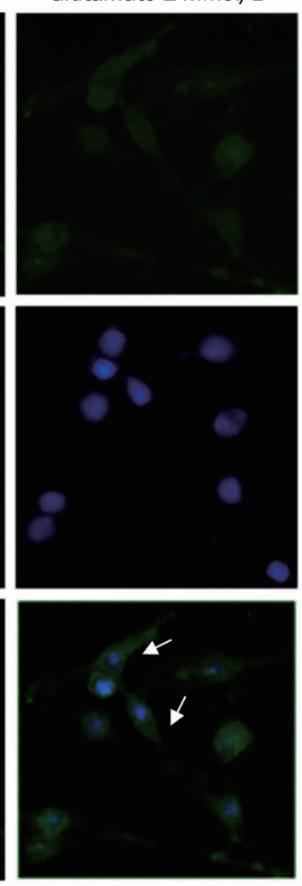

Glutamate $1 \mathrm{mmol} / \mathrm{L}$ +Carbachol $0.01 \mu \mathrm{mol} / \mathrm{L}$
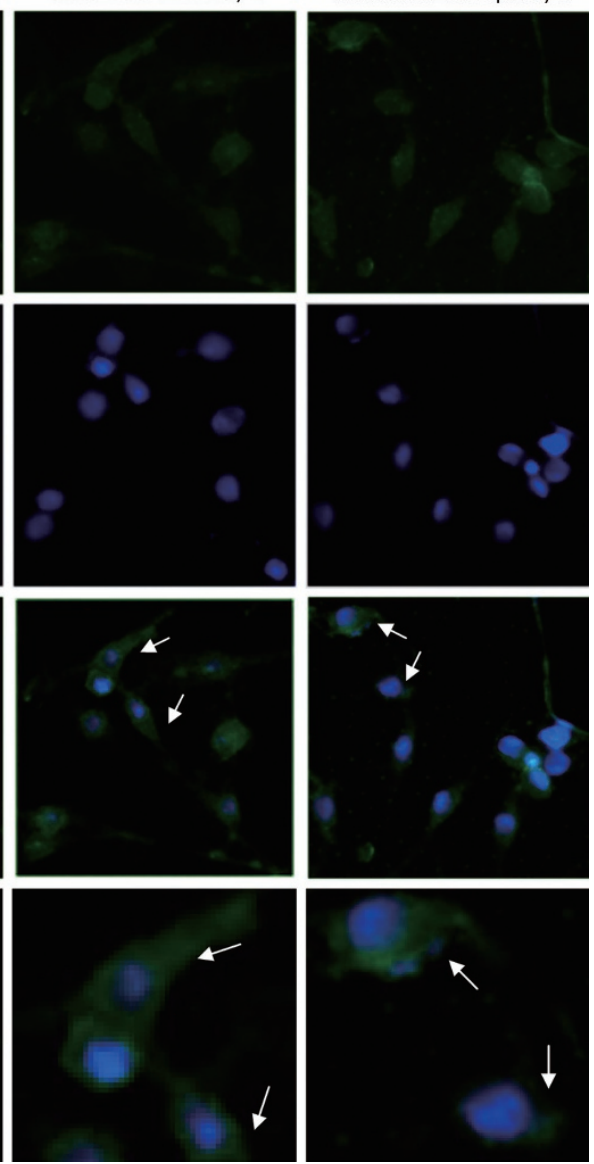

Figure 3. Carbachol rescued the loss of nuclear $\beta$-catenin induced by glutamate. PC12 cells were exposed to 1 mmol/L glutamate with or without pretreatment of $0.01 \mu \mathrm{mol} / \mathrm{L}$ carbachol for $24 \mathrm{~h}$. (A) Corresponding to the prior treatment, total amount of $\beta$-catenin in PC12 cells was detected by Western blotting. (B) Immunofluorescence analysis showed the $\beta$-catenin (FITC, green) and nuclei (DAPI, blue). (C) The amount of $\beta$-catenin in the cytoplasm was detected by Western blotting. 
with $0.01 \mu \mathrm{mol} / \mathrm{L}$ carbachol increased nuclear localization of $\beta$-catenin compared to $1 \mathrm{mmol} / \mathrm{L}$ glutamate treatment alone (Figure 3B). Cytoplasm was extracted using a nuclear and cytoplasmic protein extraction kit and probed for $\beta$-catenin protein levels. Consistent with the decreased nuclear localization detected by immunofluorescence, higher levels of $\beta$-catenin were found in the cytoplasm after $1 \mathrm{mmol} / \mathrm{L}$ glutamate treatment by immunoblot. Carbachol attenuated this effect (Figure 3C).

Carbachol alleviated glutamate inhibition of $\beta$-catenin transcriptional activity in PC12 cells

After accumulating and stabilizing in the cytoplasm, $\beta$-catenin translocates to the nucleus where it interacts with Tcf/LEF transcription factors, inducing the expression of Wnt target genes. These are important events in neural development and maintenance ${ }^{[30]}$

Glutamate inhibited $\beta$-catenin translocation to the nucleus. $\beta$-Catenin transcriptional activity was evaluated with a luciferase assay and by measuring mRNA levels of Wnt target genes after $1 \mathrm{mmol} / \mathrm{L}$ glutamate treatment for $8 \mathrm{~h}$. PC12 cells were transfected using TOP-FLASH, which drives high levels of luciferase activity in response to Wnt signaling activity. Glutamate $(1 \mathrm{mmol} / \mathrm{L})$ treatment for $8 \mathrm{~h}$ decreased $\beta$-catenin transcriptional activity to $69.02 \%$ of control levels (Figure $4 \mathrm{~A}$ ). Exposure to glutamate reduced engrailed-2, connexin 43 , and cyclin D1 mRNA levels to $40.17 \%, 28.81 \%$, and $43.60 \%$ of control levels, respectively. Pretreatment with $0.01 \mu \mathrm{mol} / \mathrm{L}$ carbachol increased transcriptional activity to $165.10 \%$ of control levels and increased engrailed-2, connexin 43 , and cyclin D1 mRNA levels to $304.56 \%, 93.36 \%$ and $156.23 \%$ control levels, respectively (Figure 4B).

\section{Discussion}

The hypothesis of glutamate excitotoxicity argues that excessive glutamate causes neuronal dysfunction and degeneration $^{[14]}$. Understanding the mechanism underlying the excitotoxic process may lead to a better understanding of neurodegenerative disorders. The GSK-3 $\beta / \beta$-catenin pathway has recently been shown to modulate many fundamental cell processes, and GSK-3 $\beta$ itself is involved in the pathology of $\mathrm{AD}^{[31,32]}$.

Among cell lines of neuronal origin, PC12 cells are selectively affected by the cytotoxic effect of glutamate ${ }^{[33]}$. The present work utilized a well-established experimental method where PC12 cells are treated with glutamate. Glutamateinduced neurotoxicity was accompanied by GSK-3 $\beta$ overactivation, which was inhibited by $\mathrm{mAChR}$.

Previous studies demonstrated that glutamate can decrease GSK-3 $\beta$ activity in hippocampal slices, which may contribute to neurotoxicity in the hippocampus ${ }^{[34]}$. The present work established that glutamate causes PC12 cell death in a dosedependent manner, accompanied by GSK-3 $\beta$ overactivation. Unlike most kinases, GSK-3 $\beta$ is constitutively active in cells. Activity can be dynamically inhibited by phosphorylation at Ser9 and stimulated by phosphorylation at Tyr216 $6^{[35]}$. Unlike
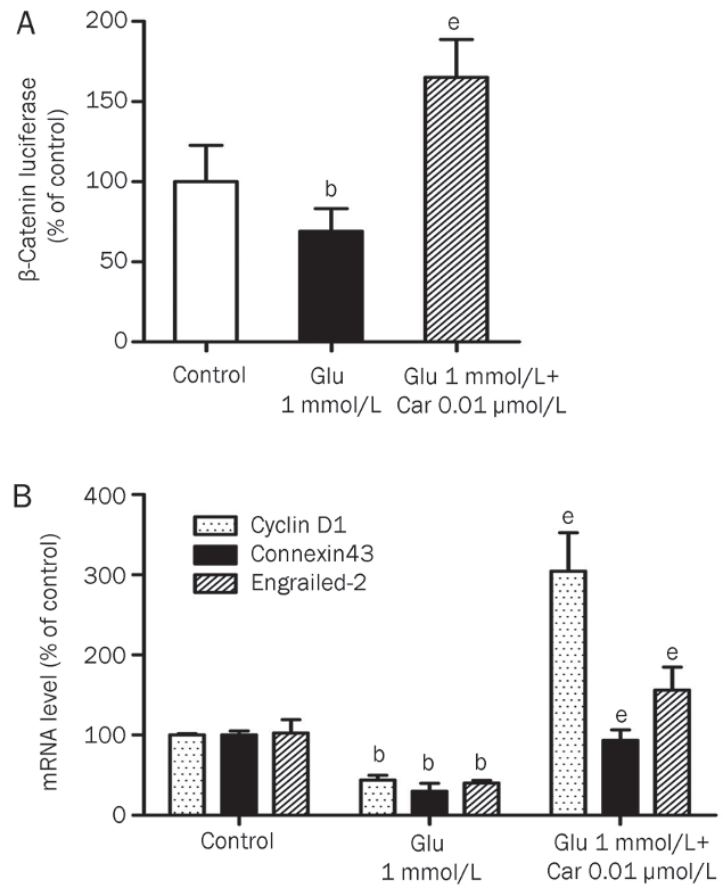

Figure 4. Effects of glutamate and pre-treatment of carbachol on $\beta$-catenin transcriptional activity and Wnt target gene expression in PC12 cells. PC12 cells were exposed to $1 \mathrm{mmol} / \mathrm{L}$ glutamate with or without pre-treatments of $0.01 \mu \mathrm{mol} / \mathrm{L}$ carbachol for $24 \mathrm{~h}$. (A) TOP-FLASH was transfected into PC12 cells and the cells were treated as described above. Luciferase activity was determined after $8 \mathrm{~h}$. Relative changes in expression are shown compared with the levels of TOP-FLASH in untreated cells. (B) After 8 h, PC12 cells were harvested and RNA was prepared. mRNA levels for cyclin D1, connexin43, engrailed-2 were evaluated by real-time $\mathrm{PCR}$ analysis. Data represent mean $\pm \mathrm{SD}$ of three independent experiments. ${ }^{\mathrm{b}} P<0.05$ vs control group. ${ }^{\mathrm{e}} P<0.05$ vs injury group.

previous publications, which measured phosphorylation at Tyr216, the present work evaluated phosphorylation at Ser9. Ser9 phosphorylation renders GSK-3 $\beta$ inactive and thus is implicated in neuronal survival ${ }^{[21]}$. Glutamate decreased GSK-3 $\beta$ phosphorylation at Ser9, indicating that GSK-3 $\beta$ is overactivated during glutamate-induced neurotoxicity. Consistent with these findings, glutamate led to GSK-3 $\beta$ activation, resulting in reduced accumulation of nuclear $\beta$-catenin and reduced enhancement of transcriptional activity.

Next, we demonstrated that the muscarinic agonist carbachol protects PC12 cells from glutamate-induced cytotoxicity. $\mathrm{mAChR}$ is primarily responsible for these neuroprotective effects, as these effects can be antagonized by an mAChR or M1 mAChR antagonist. This finding is consistent with the

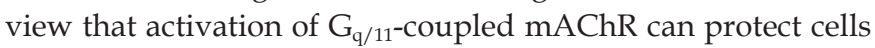
against apoptosis induced by variety of stimuli ${ }^{[8]}$. This finding is also consistent with recent reports stating that $\mathrm{mAChR}$ activation has neuroprotective effects in attenuating the progression of $\mathrm{AD}^{[5]}$. More importantly, the present work established that the neuroprotective effect of carbachol occurs through the inhibition of GSK-3 $\beta$ during glutamate treatment. These find- 
ings are highly interesting in light of the well-established link between cell survival and GSK-3 $\beta$ : while apoptotic processes involve GSK-3 $\beta$ activation, anti-apoptotic signaling includes GSK-3 $\beta$ inhibition ${ }^{[21,36,37]}$.

Inactivation of GSK-3 $\beta$ by phosphorylation at Ser9 can increase the stabilization of $\beta$-catenin, which promotes its nuclear translocation ${ }^{[38]}$. Augmented $\beta$-catenin signaling is an anti-apoptotic stimulus ${ }^{[39]}$. To further examine the finding that $\mathrm{mAChR}$ activation can inhibit glutamate-induced GSK-3 $\beta$ overactivation, we assayed the stability and localization of $\beta$-catenin. After treatment with $1 \mathrm{mmol} / \mathrm{L}$ glutamate, the total quantity of $\beta$-catenin did not change, but less $\beta$-catenin localized to the nuclei, which decreased its transcriptional activity. Carbachol reversed these effects of glutamate.

In summary, $\mathrm{AD}$ is a complex disorder of the central nervous system. Different etiological hypotheses on the origins of $\mathrm{AD}$ are based on different histopathological lesions found in the brains of $\mathrm{AD}$ patients. $\mathrm{mAChR}$ has long been a highprofile target for AD treatment because its manipulation may restore cholinergic hypofunction. Small-molecule inhibitors of GSK-3 $\beta$ have also attracted significant attention because GSK-3 $\beta$ is a key signaling molecule in the etiology of $\mathrm{AD}^{[40,41]}$. Our study provides evidence that GSK-3 $\beta$ may be directly involved in pathways leading to glutamate-induced cell death and that $\mathrm{mAChR}$ activation exerts a neuroprotective effect by inhibiting GSK-3 $\beta$ overactivation. These results provide a new explanation for the benefits experienced by AD patients treated with $\mathrm{mAChR}$ activation - mAChR activation inhibits the overactivation of the GSK-3 $\beta$ signaling pathway.

\section{Acknowledgements}

This work was supported by the National Natural Science Foundation of China (grant No 30873057 and 81171245) and the Key Basic Project of the Shanghai Municipal Science and Technology Commission, China (№ 08JC1413600 and 11JC1406600).

\section{Author contribution}

Ke MA performed research and wrote the paper; Li-min YANG contributed new reagents; Hong-zhuan CHEN contributed to the experimental design; Yang LU is the corresponding author.

\section{References}

1 Shah RS, Lee HG, Xiongwei Z, Perry G, Smith MA, Castellani RJ. Current approaches in the treatment of Alzheimer's disease. Biomed Pharmacother 2008; 62: 199-207.

2 Ladner CJ, Lee JM. Pharmacological drug treatment of Alzheimer disease: the cholinergic hypothesis revisited. J Neuropathol Exp Neurol 1998; 5: 719-31.

3 Fisher A. Therapeutic strategies in Alzheimer's disease: M1 muscarinic agonists. Jpn J Pharmacol 2000; 84: 101-12.

4 Longo FM, Massa SM. Neuroprotective strategies in Alzheimer's disease. NeuroRx 2004; 1: 117-27.

5 Caccamo A, Fisher A, LaFerla FM. M1 agonists as a potential diseasemodifying therapy for Alzheimer's disease. Curr Alzheimer Res 2009; 6: 112-7.
6 Tobin AB, Budd DC. The anti-apoptotic response of the $\mathrm{G}_{\mathrm{q} / 11}$-coupled muscarinic receptor family. Biochem Soc Trans 2003; 31: 1182-5.

7 Farias GG, Godoy JA, Hernandez F, Avila J, Fisher A, Inestrosa NC. M1 muscarinic receptor activation protects neurons from beta-amyloid toxicity. A role for Wnt signaling pathway. Neurobiol Dis 2004; 17: 337-48.

8 De Sarno P, Shestopal SA, King TD, Zmijewska A, Song L, Jope RS. Muscarinic receptor activation protects cells from apoptotic effects of DNA damage, oxidative stress, and mitochondrial inhibition. J Biol Chem 2003; 278: 11086-93.

9 Lindenboim L, Pinkas-Kramarski R, Sokolovsky M, Stein R. Activation of muscarinic receptors inhibits apoptosis in PC12M1 cells. J Neurochem 1995; 64: 2491-9.

10 Choi DW. Glutamate neurotoxicity and diseases of the nervous system. Neuron 1988; 1: 623-34.

11 Olney JW. Excitotoxicity: an overview. Can Dis Wkly Rep 1990; 16 : 47-57.

12 Doble A. The role of excitotoxicity in neurodegenerative disease: implications for therapy. Pharmacol Ther 1999; 81: 163-221.

13 Dong XX, Wang Y, Qin ZH. Molecular mechanisms of excitotoxicity and their relevance to pathogenesis of neurodegenerative diseases. Acta Pharmacol Sin 2009; 30: 379-87.

14 Lau A, Tymianski M. Glutamate receptors, neurotoxicity and neurodegeneration. Pflugers Arch 2010; 460: 525-42.

15 Guan ZZ. Cross-talk between oxidative stress and modifications of cholinergic and glutaminergic receptors in the pathogenesis of Alzheimer's disease. Acta Pharmacol Sin 2008; 29: 773-80.

16 Dale TC. Signal transduction by the Wnt family of ligands. Biochem J 1998; 329: 209-23.

17 Rubinfeld B, Albert I, Porfiri E, Fiol C, Munemitsu S, Polakis P. Binding of GSK3beta to the APC-beta-catenin complex and regulation of complex assembly. Science 1996; 272: 1023-6.

18 Frame S, Cohen P. GSK3 takes centre stage more than 20 years after its discovery. Biochem J 2001; 359: 1-16.

19 Carmichael J, Sugars KL, Bao YP, Rubinsztein DC. Glycogen synthase kinase-3beta inhibitors prevent cellular polyglutamine toxicity caused by the Huntington's disease mutation. J Biol Chem 2002; 277: 33791-8.

20 Maggirwar SB, Tong N, Ramirez S, Gelbard HA, Dewhurst S. HIV-1 Tatmediated activation of glycogen synthase kinase-3beta contributes to Tat-mediated neurotoxicity. J Neurochem 1999; 73: 578-86.

21 Pap M, Cooper GM. Role of glycogen synthase kinase-3 in the phosphatidylinositol 3-Kinase/Akt cell survival pathway. J Biol Chem 1998; 273: 19929-32.

22 Tong N, Sanchez JF, Maggirwar SB, Ramirez SH, Guo H, Dewhurst $\mathrm{S}$, et al. Activation of glycogen synthase kinase 3 beta (GSK-3beta) by platelet activating factor mediates migration and cell death in cerebellar granule neurons. Eur J Neurosci 2001; 13: 1913-22.

23 Jacobs KM, Bhave SR, Ferraro DJ, Jaboin JJ, Hallahan DE, Thotala D. GSK-3beta: a bifunctional role in cell death pathways. Int J Cell Biol 2012; 2012: 930710.

24 Forlenza OV, Spink JM, Dayanandan R, Anderton BH, Olesen OF, Lovestone $\mathrm{S}$. Muscarinic agonists reduce tau phosphorylation in nonneuronal cells via GSK-3beta inhibition and in neurons. J Neural Transm 2000; 107: 1201-12.

25 del Ser T, Steinwachs KC, Gertz HJ, Andres MV, Gomez-Carrillo B, Medina M, et al. Treatment of Alzheimer's disease with the GSK-3 inhibitor tideglusib: a pilot study. J Alzheimers Dis 2013; 33: 205-15.

26 Fisher A. M1 muscarinic agonists target major hallmarks of Alzheimer's disease - an update. Curr Alzheimer Res 2007; 4: 577 80. 
27 Martinez A, Alonso M, Castro A, Perez C, Moreno FJ. First non-ATP competitive glycogen synthase kinase 3 beta (GSK-3beta) inhibitors: thiadiazolidinones (TDZD) as potential drugs for the treatment of Alzheimer's disease. J Med Chem 2002; 45: 1292-9.

28 Goode N, Hughes K, Woodgett JR, Parker PJ. Differential regulation of glycogen synthase kinase-3 beta by protein kinase $\mathrm{C}$ isotypes. J Biol Chem 1992; 267: 16878-82.

29 Shaw M, Cohen P, Alessi DR. Further evidence that the inhibition of glycogen synthase kinase-3beta by IGF-1 is mediated by PDK1/PKBinduced phosphorylation of Ser-9 and not by dephosphorylation of Tyr216. FEBS Lett 1997; 416: 307-11.

30 Patapoutian A, Reichardt LF. Roles of Wnt proteins in neural development and maintenance. Curr Opin Neurobiol 2000; 10: 392-9.

31 Eldar-Finkelman $\mathrm{H}$. Glycogen synthase kinase 3: an emerging therapeutic target. Trends Mol Med 2002; 8: 126-32.

32 Sereno L, Coma M, Rodriguez M, Sanchez-Ferrer P, Sanchez MB, Gich I, et al. A novel GSK-3beta inhibitor reduces Alzheimer's pathology and rescues neuronal loss in vivo. Neurobiol Dis 2009; 35: 359-67.

33 Froissard P, Duval D. Cytotoxic effects of glutamic acid on PC12 cells. Neurochem Int 1994; 24: 485-93.

34 Lee JH, Lee EO, Kang JL, Chong YH. Concomitant degradation of betacatenin and GSK-3 beta potently contributes to glutamate-induced neurotoxicity in rat hippocampal slice cultures. J Neurochem 2008; 106: 1066-77.
35 Bhat RV, Shanley J, Correll MP, Fieles WE, Keith RA, Scott CW, et al. Regulation and localization of tyrosine216 phosphorylation of glycogen synthase kinase-3beta in cellular and animal models of neuronal degeneration. Proc Natl Acad Sci U S A 2000; 97: 11074-9.

36 Hetman M, Cavanaugh JE, Kimelman D, Xia Z. Role of glycogen synthase kinase-3beta in neuronal apoptosis induced by trophic withdrawal. J Neurosci 2000; 20: 2567-74.

37 Crowder RJ, Freeman RS. Glycogen synthase kinase-3 beta activity is critical for neuronal death caused by inhibiting phosphatidylinositol 3-kinase or Akt but not for death caused by nerve growth factor withdrawal. J Biol Chem 2000; 275: 34266-71.

38 Hart MJ, de los Santos R, Albert IN, Rubinfeld B, Polakis P. Downregulation of beta-catenin by human Axin and its association with the APC tumor suppressor, beta-catenin and GSK3 beta. Curr Biol 1998; 8: 573-81.

39 Li HL, Wang HH, Liu SJ, Deng YQ, Zhang YJ, Tian Q, et al. Phosphorylation of tau antagonizes apoptosis by stabilizing beta-catenin, a mechanism involved in Alzheimer's neurodegeneration. Proc Natl Acad Sci U S A 2007; 104: 3591-6.

40 Giese KP. GSK-3: a key player in neurodegeneration and memory. IUBMB Life 2009; 61: 516-21.

41 Medina M, Avila J. Glycogen synthase kinase-3 (GSK-3) inhibitors for the treatment of Alzheimer's disease. Curr Pharm Des 2010; 16 : 2790-8. 